\title{
Textile Clothing Industry of Henan Province and Its Promotion to Henan Economy
}

\author{
Ruixia YAN ${ }^{1,2}$ \\ ${ }^{1}$ Tianjin Polytechnic University, Tianjin, 300387, China \\ ${ }^{2}$ Zhongyuan University of Technology, Zhengzhou, 450007, China \\ $43188940 \underline{\text { @ qq.com }}$
}

\begin{abstract}
Based on the related data of the textile clothing data in Henan Province, the promotion of textile clothing industry to Henan economic was researched through the Engle-Granger method. Then the direct pull degree and contribution rate of textile clothing industry to Henan economic were examined through the definition of direct pull degree and contribution rate. Results shows the textile clothing industry had more obvious role in promoting Henan economic growth, but this role reached the peak in 2003 before declining slowly in recent years.
\end{abstract}

KEYWORD: Textile clothing industry; Henan Province; Engle-Granger method; Direct pull degree; Contribution rate.

\section{INTRODUCTION}

Textile clothing industry is the important industry of the people's livelihood and export advantage industry in China. In recent years Chinese textile clothing export accounted for over $30 \%$ of the international market share [1] and about $13 \%$ of total Chinese exports [2]. Although faces from other lowwage countries such as Cambodia, Vietnam, Bangladesh's competition, the textile clothing exports continue to play the most important role in the international market due to complete industry chain [3].

In recent years, textile clothing industry migrated from coastal to inland due to the limitation of labor, land prices, the factors of environment and resources [4]. As the most populous province and the secondmost cotton production province in China, Henan Province is suitable for textile clothing industry transfer form coastal regions due to enough labor resource and enough cotton resource.

Over the years, Henan Province has treated the textile clothing industry as a traditional advantage industry and has become a veritable textile province due to textile clothing industry transfer form coastal regions. Compared to the provinces with large export of the textile clothing, such as Zhejiang Province, Guangdong Province, Jiangsu Province, Fujian Province, Shandong Province, Shanghai City, the textile clothing production amount of Henan Province was large but the textile clothing industry was not strong. But the textile clothing industry of
Henan Province also has its own characteristics. Some researchers analyzed the textile clothing industry of Henan Province. Xu [5] analyzed textile clothing export of Henan Province. Duan [6] researched the competitiveness of the textile clothing industry of Henan Province using the "diamond model". Yue et al. [7] described the current situation of the textile clothing industry of Henan Province, putting forward the related problems. Zhou [8] studied the textile industry development in Henan Province based on the SWOT analysis. However, the qualitative analysis instead of the quantitative analysis was adopted in the above literature.

Because the textile clothing industry of Henan Province has an important position in the national textile clothing industry, and has an unique contribution, it is necessary to research the textile clothing industry of Henan Province and its promotion to Henan economy based on the above literature.

The authors researched the textile clothing industry of Henan Province using Revealed Comparative Advantage (RCA) Index [9] the datum of 1990 to 2013. This paper would research the textile clothing industry of Henan Province and its promotion to Henan economy based on previous research results and relative literature through the Engle-Granger method. Then the direct pull degree and the contribution rate of textile clothing industry to Henan economic were examined through the definition of direct pull degree and contribution rate. 


\section{THE SITUATION OF HENAN TEXTILE CLOTHING INDUSTRY}

At present, Henan province has become a veritable textile province. Yarn production was 6.07776 billion tons in 2013, ranking second in China. Clothing production and cloth production in 2013 were 1.22813 billion set and 3.13367 billion meters, respectively, both ranking seventh in China. Textile clothing export of Henan Province was \$2.087 billion in 2013, among the 18th place in China.

Textile clothing industry of Henan Province developed very rapidly in recent years. Henan annual output value, industrial production, annual exports increase from 7.883 billion yuan, 2.004 billion yuan $\$ 368$ million in 1990 , to 269.464 billion yuan, 82.089 billion yuan, $\$ 2.056$ billion in 2013. In addition to the individual year as exports fell slightly in 2009, the annual production, industrial production and export of other years has been growing, suggesting the development of textile clothing industry of Henan Province over the years, and the trend of textile clothing industry transfer form coastal regions. Fig.1 shows the situation of Henan textile clothing industry from 1990 to 2013.

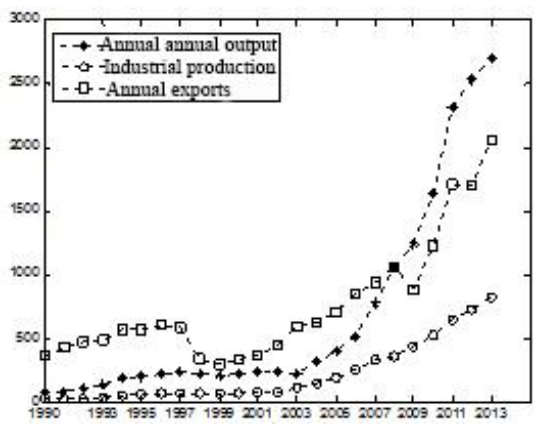

Fig.1 The situation of Henan textile clothing industry

"Henan Statistical Yearbook" and "China Statistical Yearbook" takes the "yarn" and "cloth" as the major industrial products, so Fig.2 shows the ratio of Henan "yarn" and "cloth" to Chinese "yarn" and "cloth" in 1990 2013. It can be seen from Fig. 2 that the ratio of Henan "yarn" to Chinese "yarn" increased from $6.80 \%$ in 1990 to $17.77 \%$ in 2013, while the ratio of Henan "cloth" to Chinese "cloth" varied from $3.18 \% \sim 6.64 \%$. The ratio of Henan textile clothing production to Chinese textile clothing production changed slowly for many years, varying from $3.43 \%$ in 1990 to $4.71 \%$ in 2013 . The ratio of Henan textile clothing export to Chinese textile clothing export slowly decreased for many years, varying from $2.19 \%$ in 1990 to $0.70 \%$ in 2013.

In four processes of the textile clothing industry (spinning, weaving, dyeing, clothing), the spinning industry of Henan Province was strength, and dyeing was the bottleneck. Four processes were serious unbalanced. For example, seventy percent of Henan fabric was transported to south for dyeing, while the clothing needed should buy from south. Imbalance of the industrial chain has increased the production cost of textile clothing enterprises in Henan Province, which reduces the production efficiency and market competitiveness of the enterprise.

\section{THE PROMOTION OF TEXTILE CLOTHING INDUSTRY TO ECONOMY}

\subsection{The Selection of Variable}

The textile clothing industry added value of Henan Province $(Z)$ was chosen as independent variable, and Gross Domestic Product (GDP) was chosen as dependent variable. Then the promotion of the textile clothing industry of Henan Province to the Henan economy was researched by using the EngleGranger method. To eliminate possible heteroskedasticity, the natural logarithm for the independent variable and the dependent variable was adopted in the solving process, i.e. $\ln G D P 、 \ln Z$. Application software was Eviews6.0.

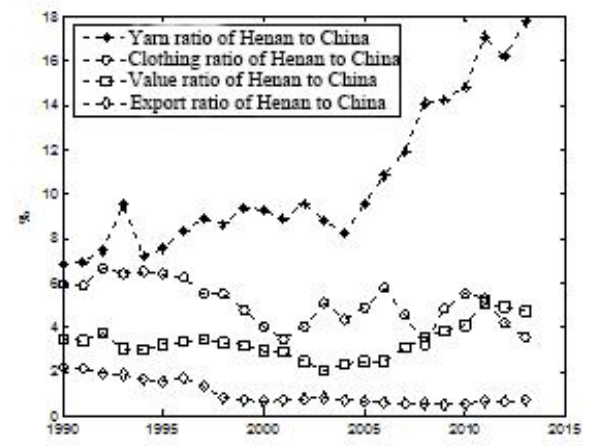

Fig.2 The ratio of Henan "yarn" and "cloth" to Chinese "yarn" and "cloth"

\subsection{The Unit Root Test}

The stationarity test was used to determine whether there was a cointegration relationship. Here ADF test, the most common method of the unit root test was adopted according to the AIC criterion. TABLE I shows the result of the ADF test. It can be seen from the TABLE I that $\ln G D P$ and $\ln Z$ are both single integer sequences, which means that there is a cointegration relationship between $\ln G D P$ and $\ln Z$. So the cointegration test can be used.

TABLE 1 Result of the ADF Test

\begin{tabular}{|c|c|c|c|c|}
\hline Variable & $\begin{array}{c}\text { Test Type } \\
(\mathrm{c}, \mathrm{t}, \mathrm{k})\end{array}$ & $\begin{array}{c}\text { ADF } \\
\text { Value }\end{array}$ & $\begin{array}{c}\text { Critical } \\
\text { Value }\end{array}$ & $\begin{array}{c}\text { Whether } \\
\text { smooth }\end{array}$ \\
\hline $\ln G D P$ & $(\mathrm{c}, \mathrm{t}, 1)$ & -1.710781 & $-2.89 * * *$ & No \\
\hline $\ln Z$ & $(\mathrm{c}, \mathrm{t}, 1)$ & -2.061284 & $-2.89 * * *$ & No \\
\hline$\Delta \ln G D P$ & $(\mathrm{c}, \mathrm{t}, 1)$ & -4.886925 & $-3.77 *$ & Yes \\
\hline$\triangle \ln Z$ & $(\mathrm{c}, \mathrm{t}, 1)$ & -3.421501 & $-3.19 * *$ & Yes \\
\hline
\end{tabular}

Notes: (c, t, k) denote constant terms, time trend, and lag order number, respectively, $\triangle$ denotes the first order difference operator, $* * *, * *$ and $*$ denote $10 \%$ significant level, $5 \%$ significant level, and $1 \%$ significant level, respectively. 


\subsection{The Engle-Granger Method}

Because there is a cointegration relationship between $\ln G D P$ and $\ln Z$ and the cointegration test can be carried out:

$$
\ln G D P=a+b \ln Z+e
$$

The relationship between $\ln G D P$ and $\ln Z$ can be regressed by the orthogonal least-squares (OLS):

$$
\ln G D P=4.446269+0.904111 \ln Z
$$

$t$ value $(27.43305)(27.27880)$

Regression results show that $R^{2} \approx 0.971284$. The associated probability of F-test was calculated as 0.000000 , which means variables in equation significantly, good fitting effect, and highly linear between variables.

The value of Durbin-Watson in (2) was 0.351635 . For samples with sample size of 24 and one explanatory variable, $\mathrm{dt}=1.27$ and $\mathrm{du}=1.45$ when significant level is 5\% using Durbin-Watson test according to corresponding tables. Because the value of Durbin-Watson 0.351635 is lower than $\mathrm{dt}=1.27$, so Residual error sequence is a first order correlation.

In order to eliminate the correlation, the Cochrane - Orcutt iteration method was used to deal with residual error. Results show the value of DurbinWatson was 2.143953, with du < DW < 4-du, which suggested that residual autocorrelation phenomenon has been basically eliminated after using the Cochrane-Orcutt iteration method. Furthermore, $R^{2} \approx 0.965327$, close to the value before processing. The unit root test for treated residual error sequence shows that treated residual error is stationary series, there is no unit root, and other statistics are more reasonable. So (2) can be transformed into:

$$
\ln G D P=6.006090+0.313913 \ln Z
$$

$t$ value (6.006090) (3.334070)

TABLE II ADF Test for Residual error sequence

\begin{tabular}{|c|c|c|c|c|c|}
\hline $\begin{array}{c}\text { Test } \\
\text { Type } \\
(\mathrm{c}, \mathrm{t}, \mathrm{k})\end{array}$ & $\begin{array}{c}\text { ADF } \\
\text { Value }\end{array}$ & $\begin{array}{c}1 \% \\
\text { Critical } \\
\text { Value }\end{array}$ & $\begin{array}{c}5 \% \\
\text { Critical } \\
\text { Value }\end{array}$ & $\begin{array}{c}10 \% \\
\text { Critical } \\
\text { Value }\end{array}$ & $\begin{array}{c}\text { Whether } \\
\text { smooth }\end{array}$ \\
\hline$(\mathrm{c}, \mathrm{t}, 1)$ & $\begin{array}{c}- \\
4.977149\end{array}$ & -3.77 & -3.19 & -2.89 & Yes \\
\hline
\end{tabular}

Elastic coefficient of $\ln Z$ in (4) is 0.313913, which meant there is a more noticeable dynamic relationship between the textile clothing industry of Henan Province and Henan economy growth. At the same time, textile clothing industry of Henan Province had obvious role in promoting economic growth, which is consistent with the reality.

\section{THE DIRECT PULL DEGREE AND CONTRIBUTION RATE OF THE TEXTILE CLOTHING INDUSTRY}

On the basis of the national income identity [9], the direct pull degree and contribution rate of the textile clothing industry for economic growth and industrial growth were defined as:

$$
\begin{gathered}
C T G=\left(V a_{1}-V a_{0}\right) / G D P_{0} \\
C T I=\left(V a_{1}-V a_{0}\right) / V a_{T} \\
C R G=C T G / R_{G D P} \\
C R I=C T I / R_{V a}
\end{gathered}
$$

Where $C T G, C T I, C R G, C R I$ denote the direct pull degree of the textile clothing industry for economic growth of Henan Province, the direct pull degree of the textile clothing industry for industrial growth of Henan Province, the contribution rate of the textile clothing industry for economic growth of Henan Province, the contribution rate of the textile clothing industry for industrial growth of Henan Province, respectively. $V a_{0}, V a_{1}, V a_{T}$ denote the textile clothing industrial growth of Henan Province in the previous year, the textile clothing industrial growth of Henan Province in that year, the total industrial growth of Henan Province in the previous year, respectively. $G D P_{0}, R_{G D P}, R_{V a}$ denote Gross Domestic Product (GDP) of Henan Province in the previous year, GDP growth rate of Henan Province in the previous year, industry growth rate of Henan Province in the previous year, respectively.

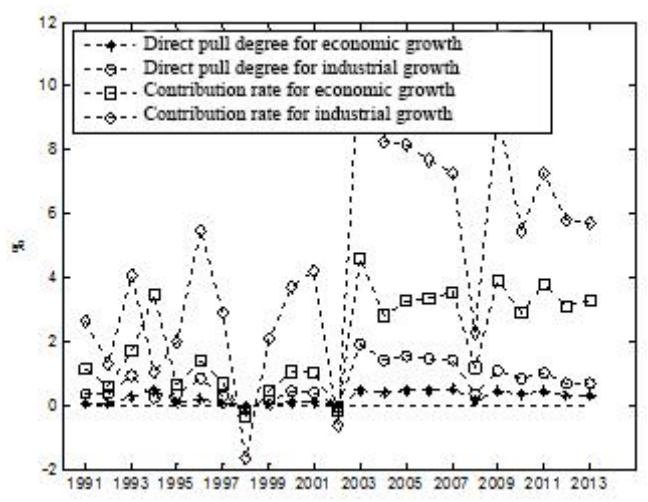

Fig.3 The direct pull degree and contribution rate of the textile clothing industry

Fig. 3 shows the direct pull degree and contribution rate of the textile clothing industry. It can be seen from Fig. 3 that the directly pull degree and the contribution rate were all positive except for 1998 and 2002, which means textile clothing industry had a positive effect on the economic growth and industrial growth of Henan Province. During $1991 \sim 2013$ the direct pull degree of the textile clothing industry for economic growth of Henan Province, the direct pull degree of the textile 
clothing industry for industrial growth of Henan Province, the contribution rate of the textile clothing industry for economic growth of Henan Province, the contribution rate of the textile clothing industry for industrial growth of Henan Province were $0.25 \%$, $0.72 \%, 2.06 \%$ and $4.59 \%$ respectively. During 2003 2013 the direct pull degree of the textile clothing industry for economic growth of Henan Province, the direct pull degree of the textile clothing industry for industrial growth of Henan Province, the contribution rate of the textile clothing industry for economic growth of Henan Province, the contribution rate of the textile clothing industry for industrial growth of Henan Province were 0.39\%, $1.12 \%, 3.25 \%$ and $7.14 \%$ respectively. Relatively, during 1991 2002 the direct pull degree of the textile clothing industry for economic growth of Henan Province, the direct pull degree of the textile clothing industry for industrial growth of Henan Province, the contribution rate of the textile clothing industry for economic growth of Henan Province, the contribution rate of the textile clothing industry for industrial growth of Henan Province were $0.12 \%$, $0.35 \%, 0.97 \%$ and $2.25 \%$ respectively.

This shows that the textile clothing industry can stronger pull the economic growth and the industrial growth in the recent ten years. It also can be seen from Fig. 3 that the pull function reached the peak in 2003 before declining slowly in recent years.

\section{CONCLUSION}

Based on the related data of the textile clothing data in Henan Province, the promotion of textile clothing industry to Henan economic was researched through the Engle-Granger method. Then the direct pull degree and contribution rate of textile clothing industry to Henan economic were examined through the definition of direct pull degree and contribution rate. The conclusions are as follows:

The textile clothing industry added value of Henan Province $(Z)$ was chosen as independent variable, and Gross Domestic Product (GDP) was chosen as dependent variable. The textile clothing industry of Henan Province and its promotion to Henan economy was researched through the EngleGranger method. $\ln G D P$ and $\ln Z$ were both single integer sequences, which means that there is a cointegration relationship between $\ln G D P$ and $\ln Z$ according to the unit root test. The regressed equation was obtained by using the Engle-Granger method after the correlation was eliminated by the
Cochrane - Orcutt iteration method. Results show there was a more noticeable dynamic relationship between the textile clothing industry of Henan Province and Henan economy growth. At the same time, textile clothing industry of Henan Province had obvious role in promoting economic growth, which was consistent with the reality.

The directly pull degree and the contribution rate were all positive except for 1998 and 2002, which means textile clothing industry had a positive effect on the economic growth and industrial growth of Henan Province. The textile clothing industry can stronger pull the economic growth and the industrial growth in the recent ten years, and the pull function reached the peak in 2003 before declining slowly in recent years.

\section{ACKNOWLEDGEMENT}

This research was supported by the Henan Province Soft Science Project (No. 102400450271).

\section{REFERENCES}

[1] Z. Lu, "Present situation and promoting path of international competitiveness of China's textile industry," Shanghai Textile Science \& Technology, vol.42, no.2, pp.1-4, 2014.

[2] R. Yang, L. Liu, and Y. Ren, "Thermal environment in the cotton textile workshop," Energy and Buildings, vol. 102, pp. 432-441, 2015.

[3] R. Yang, L. Liu, and Y. Zhou, "Predicted Thermal Sensation Index for the Hot Environment in the Spinning Workshop," Mathematical Problems in Engineering, vol. 2015, Article ID 980619, 8 pages, 2015. doi:10.1155/2015/980619

[4] J. Ruan and X. Zhang, "Flying geese'" in China: The textile and apparel industry's pattern of migration," Journal of Asian Economics, vol.34, pp. 79-91, 2014.

[5] Q. Xu, "The expansion of Henan textile and clothing export trade and countermeasures," Journal of Jilin Teachers Institute of Engineering and Technology, vol. 28, No. 1, pp.12-14, 2012.

[6] W. Duan, "Analysis of the cluster competitive power of Henan textile and clothing industry," Economic Survey, vol. 6, pp.30-33, 2008.

[7] L. Zhou, "Research on development of Henan textile industry Based on the SWOT analysis," Economic Research Guide, 2011, 125 (15): 179-180.

[8] R. Yan, "Research on textile clothing export of Henan Province," China Journal of commerce, Vol.12, No.3, pp.125-126, 2015.

[9] L. Xiong and K. Huang, "On the contribution of China's textiles and clothing exporting commerce to economic growth," International trade issues, Vol.11, pp.23-28, 2006. 